\title{
A magyarországi zsidó temetők kutatása és védelme
}

A sírfeliratok gyüjtésének, a temetők tudományos célú kutatásának az igénye a zsidóságban a 19. század közepéig nem jelentkezett. Emögött talán azon talmudi vélekedés (Tb Horajot 13b) áll, miszerint a sírfeliratok olvasgatása azon tíz dolog közé tartozik, ami negatívan hat a tanulásra, avagy eltérít a tanulástól. ${ }^{1}$

A héber sírfeliratok - elsősorban középkori feliratok - gyűjtésének és közzétételének első európai példáit tehát keresztény tudósok kezdeményezéseként ismerjük a 18. század utolsó harmadától kezdve. Így Johann Caspar Ulrich zürichi református lelkész 1768-ban megjelent müvében a svájci zsidóság történetét tárgyalva közölte néhány régi síremlék héber nyelvü szövegét. ${ }^{2}$ Ehhez az érdeklődéshez hozzájárulhatott az, hogy a középkorban vagy kora újkorban kiüzött zsidó közösségek egykori temetőit, sírköveit rendszerint építési anyagként használták, akár pusztán praktikus okokból, akár a diadalmaskodó kereszténység jelzésére. A városfalakba, városi középületekbe, katedrálisokba beépített vagy akár piaci kövezetként szolgáló kövek némelyikéről századokkal később is kiolvashatók voltak a sírfeliratok. ${ }^{3}$ A budai vár polgári házainak 1686 utáni újjáépítéséhez is használtak zsidó sírköveket, néhányat olyan módon, hogy valószínűleg olvashatók voltak.

A 19. század közepén több országban már állami szinten is találunk példát arra, hogy felismerik a középkori zsidó sírkövek és fragmentumok jelentőségét. Szimbolikus, bár nem végleges szemléletváltást jelez, hogy míg 1847-ben a bristoli Saint Elisabeth Hospital átépítése során elökerült középkori zsidó sírköveket még építőanyagként hasznosították újra, addig az 1849-ben Párizsban előkerült hasonló leletek már a Cluny Múzeumba kerültek. ${ }^{4}$

* A szerzők: Balogh István az ORZSE adjunktusa. E-mail: baloghi@or-zse.hu és Bányai Viktória, a TK Kisebbségkutató Intézet tudományos főmunkatársa, e-mail: banyai.viktoria@ tk.mta.hu

1 A listán egyébként olyan félelmet keltő, visszatetsző vagy felkavaró dolgok szerepelnek, mint áthaladni két teve között, egy nő áthaladása férfi között, büzlö dög mellett elmenni, nem kellöen megsült kenyeret enni vagy halott arcát nézni.

2 Ulrich, Johann Caspar: Sammlung Jüdischer Geschichten .... Basel, 1768. 39-44., 204-105.

3 Erre példákat 1. Wilke, Carsten L.: Medieval Hebrew Inscriptions: Towards a European Database. Jewish Studies at the CEU, VII (2013), 148 skk.

4 Wilke, 2013. 152-154. Az optimistának ható irányok mellett Wilke a továbbiakban számos 19. és 20. századi európai példát is felsorol az értékes leletekkel való felelötlen és érzéketlen bánásmódra a hivatalos szervek részéről. A náci időszakot pedig ismét a temetők tudatos pusztítása, megalázása jellemezte. 
Zsidó tudósok érdeklődése a régi zsidó sírkövek iránt - ahogy más történeti forrásanyag iránt is - a Wissenschaft des Judentums mozgalmának szellemiségében induló kutatásokban, az 1830-40-es években kezdődött; majd az 1840-es évektől sorra jelentek meg nyomtatásban a gyűjteményes kötetek. Leopold Zunznak, a mai értelemben vett zsidó történeti kutatás megalapítójának Das Gedächtnis der Gerechten címü, 1845-ben megjelent tanulmányát a modern epigráfiai kutatás indítómüvének tekinthetjük módszertani értelemben. Zunz átfogó írásában 210 középkori héber sírfeliratot tanulmányozott - többségében másodlagos forrásokból - felhívva a figyelmet a zsidó síremlékek történeti jelentőségére, héber irodalmi értékére és a zsidó-keresztény kapcsolatokat megvilágító szerepükre. ${ }^{5}$ Ugyanebben az évben tette közzé a pozsonyi születésű Max Emanuel Stern az általa Bécsben indított Bikkure Haitim című héber nyelvü folyóiratában azt a felhívást, amelyben kérte a hitközségeket és rabbijaikat, hogy a régi, elporladó sírkövek feliratait mentsék meg a feledéstől, mert ezekben a zsidóság „történetének fontos és megbízható kútforrásait" találhatjuk meg.

A következő időszakban egyre több helyen kezdődött meg rabbik, tudósok és a zsidó hitközségek alkalmazottainak közreműködésével a régi sírkövek dokumentálása. Az egyik első teljességre törekvő kötet, Ludwig August Frankl von Hochwart, a bécsi zsidó hitközség titkárának munkája, 1855-ben jelent meg Inschriften des Alten Jüdischen Friedhofs in Wien címmel. Módszertani szempontból Frankl kötete képezi a fél évszázaddal későbbi Bernard Wachstein kutatásainak és munkáinak előzményét, azon keresztül pedig a modern magyarországi kutatások elméleti kezdőpontjának is tekinthetjük. Azonban hasonló jellegü átfogó munkára még igen sokat kell várni. Pedig sürgetés már az 1850-es években is elhangzott: a korszak hazai zsidóságának egyik legmeghatározóbb alakja, Löw Lipót több cikkében is írt az általa szerkesztett Ben Chananjában a temetőkről és a síremlékek feliratairól, kiemelve, hogy nagyobb figyelmet érdemelnének a régi zsidó temetők. ${ }^{6}$

Ilyen jellegű felmérést, kutatást azonban a következő évtizedekben sem találunk, pontosabban csak kudarcáról értesülünk. ${ }^{7}$ Ami az 1860-as évektől megindul, az inkább nevezhető archeológiai iránynak: a minél korábbi sírkőleletek fellelése és széles körü közzététele foglalkoztatta a neológ zsidó értelmiség színe-javát, és ezt az évezredes magyar-zsidó együttélés igazolásának vágya motiválta.

5 Zunz, Leopold: Das Gedächtnis der Gerechten. In: Zur Geschichte und Litteratur. Berlin: Veit und Comp., 1845. 314-458.

6 Löw, Leopold: Blumen auf Gräbern. Ben Chananja I. (1858), 433-442

7 1888-ban jelent meg Bacher Simon felszólítása a Magyar Zsidó Szemlében, ennek Kútfök címü rovatában közölt nagyszámú okirat mellett javasolt figyelmet fordítani a régi „sírföliratok és egyéb héber nyelvü kútfők" felkutatására és publikálására is. Leírta, hogy a régi pesti zsidó temető sírfeliratainak összegyüjtésére már az 1870-es évek első felében előfizetést hirdetett, azonban nem kapott támogatást a terve. 
Deutsch Henrik, az Országos Izraelita Tanítóképző Intézet későbbi igazgatója 1866-ban tette közzé az Archaeológiai Közleményekben az 1862-ben Nagyszombatban, a városfal bontásakor előkerült kilenc darab 14. századi héber sírfeliratot és fordításaikat. 1887-ben Kohn Sámuel történész, a Pesti Izraelita Hitközség förabbija, a régi budai Fehérvári kapuba befalazott síremlékeket és a legkorábbi török kori sírkő-leletet publikálta. 1895-ben Kaufmann Dávid, a Rabbiképző Intézet professzora számolt be - nagyméretü fényképekkel is illusztrálva - az Archaeológiai Értesitőben a középkori budai krisztinavárosi zsidó temető helyén talált sírkövekről, köztük a máig is legrégebbiként számon tartott 1278-as síremlékről, ezáltal szélesebb szakmai közönség számára is bemutatva a magyarországi zsidóság korai epigráfiai emlékeit.

A krisztinavárosi leletek nyomán Kohn Sámuel az Izraelita Magyar Irodalmi Társulat Évkönyvében régészeti feltárásokat sürgetett: ${ }^{8}$

„Ki tudja, mennyi archeológiai, történelmi és felekezeti tekintetben fontos kincs rejtőzik még ott a föld mélyében. Végeztessünk ásatásokat! Lehetséges, hogy ismét csak puszta évszámokra és közömbös nevekre akadunk, de lehetséges az is, hogy az egyik vagy másik név mellett azt találjuk bevésve, hogy aki 6 vagy 700 éve előtt viselte, rabbi, vagy tudós, királyi hivatalnok, pénzverő, vagy a magyar zsidóság prefektusa volt, ha szerencsével járunk, tán még azt is, hogy a zsidó hitre tért kozárok nemzetiségéböl való, tehát azok ivadéka, kik mint a magyarok szövetségesei részt vettek a honfoglalás nagy művében."

A milleniumi ünnepségek lázában tehát már nemcsak a középkori zsidó jelenlét dokumentumait remélték a sírkövekben fellelni, és ezáltal a gyökértelenség vádját cáfolni, hanem a honfoglalás koráig, sőt - a kazár-elmélettel - a vándorlás koráig visszanyúló bizonyítékot is találni kívántak.

Igen tanulságos ebből a szempontból, hogy a két világháború közötti időszak antiszemita légkörében milyen széles összefogás jött létre - zsidó bárók, gyárosok és felsőházi képviselők támogatásával - arra, hogy a Zsidó Múzeum tulajdonába kerüljön egy i.e. 3. századi, vagyis a Pannónia provinciából származó zsidó sírkő. ${ }^{9}$ „A magyar zsidók nemesi levele”, amely bizonyítani volt hivatott, hogy már a magyar honfoglalást jóval megelőzően is éltek zsidók az ország területén, 1933-ban érkezett meg a múzeumba - de mint oly sok egyéb apologetikus gesztus, semmi hatással sem volt a ,galíciai jöttmentek hadával” riogatókra.

8 Kohn Sámuel: Zsidó történelmi emlékek. Különös tekintettel Magyarországra. IMIT Évkönyv, II. (1896). 52-62.

9 3. századi zsidó sírkő Esztergomból , MILEV, accessed August 1, 2020, http://collections. milev.hu/items/show/30151. 
A temetőkben fellelhető régi sírkövek toposza, mint az ősiség bizonyítéka, az 1929-ben kiadott Magyar Zsidó Lexikon hitközség-történeti szócikkeiben ${ }^{10}$ és helytörténeti munkák erősen túlzó - és jellegénél fogva sosem dokumentált - megfogalmazásaiban a 20., sőt a 21. században is rendszeresen megjelennek. Ugyanakkor - vagy épp ezzel karöltve - még az alapos, komoly levéltári anyagra épülő zsidó helytörténeti munkák is alig szenteltek érdemi figyelmet a temetőknek. Ez egyaránt igaz Kaufmann Dávid tanítványai, fiatal rabbik által írt első magyarországi zsidó helytörténeti publikációkra, amelyek a 19. század utolsó évtizedétől kezdve jelentek meg, a Scheiber Sándor által kezdeményezett, a Magyar Izraeliták Országos Képviselete kiadásában 1966-1982 között megjelent helytörténeti sorozat köteteire, vagy akár a vészkorszak után megjelent Jizkor-kötetekre is. ${ }^{11}$

Tudomásunk szerint egészen 1990-ig mindössze egyetlen magyarországi temető korai sírfeliratainak összegyüjtésére és publikálására került sor: Goldberger Izidor tatai rabbi a tatai zsidó temetőben a maga idejében még fellelhető 18 . századi és 19. század eleji sírfeliratokat jegyezte fel. ${ }^{12}$ Tudományos értelemben mérföldkőnek számít, és ma is alapvető Scheiber Sándor 1960-ban kiadott összefoglaló munkája - Magyarországi zsidó feliratok a III. századtól 1686-ig -, ez azonban lényegében a 19. század végi archeológiai vonalat összegezte, és egészítette ki a II. világháború után elökerült leletekkel.

Toronyi Zsuzsanna a magyarországi zsidó értékek megőrzését célzó törekvések 20. századi kezdeteit tárgyalva hívja fel a figyelmet arra, hogy a kialakult zsidó tudományos intézményrendszer érdektelensége a zsidó kultúra materiális és vizuális elemei iránt a beágyazott szövegközpontú megközelítéssel, és az egyre inkább anikonikusnak tekintett hagyomány nézőpontjával magyarázható. ${ }^{13} \mathrm{Ez}$ indokolhatja azt is, hogy a síremlékek szövege iránti - legalábbis mérhető - fogékonyság, érdeklődés kialakult, de maguknak a köveknek a motívumaival, díszítéseivel elemző

10 Például Apostagon 1650-es évekből származó sírkövekről ír a lexikon, miközben az összeírások szerint a 18. század közepéig a településen nem élt egy zsidó lakos sem. Vö: Grünvald Fülöp - Scheiber Sándor: Adalékok a magyar zsidóság településtörténetéhez a XVIII. század első felében. In: Magyar-Zsidó Oklevéltár, VII. köt., Budapest: Magyar Izraeliták Országos Képviselete, 1963. 5-48. és Ujvári Péter (szerk.): Zsidó Lexikon. Budapest: A Zsidó Lexikon kiadása, 1929. 53. Balassagyarmaton 500 éves hitközséget említ, holott az első zsidók csak a 18. század elején jelentek meg. Vö: Grünvald - Scheiber, 1963. 17-18. és Ujvári, 1929. 78.

11 Jizkor-köteteknek nevezzük a jellemzően külföldön, különösen Izraelben kiadott, az egykori magyarországi zsidó közösségeknek emléket állító, többségében személyesebb hangvételü emlékkönyveket. Pl. Blasz Jenő: A mi régi Fehérgyarmatunk. Bnei Brak, 1965.; Lőwinger Abraham Albert: A vasi zsidók emlékére. H. n., Az Izraelben Élő Vas Megyei Zsidók Emlékbizottsága, 1974.; Szilágyi-Windt László: Az újpesti zsidóság története. Tel Aviv, 1975.; Aharoni (Duschinszky) Ráchel: A rákospalotai zsidó hitközség története. Tel-Aviv: Rákospalotai Emlékbizottság, 1978.

12 Goldberger Izidor, Macebot ha-risonot be-ir Tata. Hazofeh. VII. (1922), 1. 53-66.

13 Toronyi Zsuzsanna: Zsidó közösségek öröksége. Budapest: Magyar Zsidó Levéltár, 2010. 8-9. 
módon csak a 20. század végén kezdtek el foglalkozni. Az előbbi megállapítást támasztja alá, hogy a 20. század eleji Magyarországon is találkozunk - elsődlegesen az ortodox közösségekben - a nagy rabbik sírfelirata iránti érdeklődéssel. Például Stein Mayer Miksa, nagyszombati rabbi által 1905 és 1908 között szerkesztett és kiadott Magyar Rabbik című folyóiratban rendszeresen közölték a bemutatott jeles személyiségek sírfeliratát is, amelyeket a legmegbízhatóbb életrajzi forrásként és történeti dokumentumként tartottak számon.

Az ortodox rabbik responsumaikban ${ }^{14}$ ugyancsak foglalkoztak a müködö temetőkkel kapcsolatban felmerülő kérdésekkel, és ezekben általánosabb szinten is fogalmaztak meg elveket. A szabályozás alapja az volt, hogy a temető a közösség közös tulajdona. Héber terminológiával hacér mesutafin, azaz társtulajdonosok udvaraként tekintendő, vagyis nem a gyászoló magánügye egy, a korábbi hagyományoktól esetleg eltérő sírkő elhelyezése: a változások csak a közösség beleegyezésével lehetségesek.

Míg a neológ közösségek szabályzatai csak a héber teljes elhagyását akadályozták, használatát kötelező elemként őrizték, addig az ortodox oldal egyes közösségei sokkal szükebben szabták meg a nyelvi kereteket: csak héber feliratokat engedélyeztek. Latin betükkel - egyes tekintélyek szerint - még a sírköves névjegyét is tilos volt feltüntetni. ${ }^{15} \mathrm{~A}$ latin betük kapun kívül tartását valósítja meg például a budapesti Csörsz utcai ortodox temetö, ahol hosszas kutakodással is csak két női síron fedezhető fel a sírköves neve latin betükkel. Bár erre az általunk ismert rabbinikus állásfoglalások külön nem térnek ki, de a tapasztalat azt mutatja, hogy a héber mellett a szintén héber betúkkel írt jiddis és egy.egy idézet erejéig az arámi nyelv is elfogadott, illetve elfogadható volt az ortodoxia számára.

A feliratok nyelvén kívül két másik kérdést tárgyalnak a rabbinikus tekintélyek a sírkövekkel kapcsolatban az 1870-es évektől vissza-visszatérően, mint ennek a területnek neuralgikus pontjait. Egyik a sírkőre vésett ábrázolás, az elhunyt arcképének fotográfián vagy más technikával való megjelenítése, ennek tilalma. Másik az arab számok használata a polgári dátum szerinti évszám feltüntetésére, vagy akár csak a temetőlátogatót útba igazító sírkőszámozás céljából. Az arab számok tiltásában egyébként nem volt teljesen egységes a rabbik vélekedése. Talán ez az oka az olyan „köztes” megoldások kialakulásának, mint például, hogy a zsidó naptár szerinti dátumot arab számokkal vésték fel, vagyis az otthonosabb arab számokat használták, azonban mégsem a Jézus születését kezdőpontnak tekintő keresztény évszámok szerint.

\footnotetext{
14 A responsum kérdésekre - jogi, rituális vagy exegetikai kérdésekre - adott feleletek, állásfoglalások. A kérdéseket leggyakrabban egy rabbi, ritkábban magánszemély vagy közösség teszi fel, és egy megfelelő tekintéllyel bíró rabbi válaszolja meg.

15 Konkrét példákat 1. Bányai Viktória: „Derék asszonyok és jámbor férfiak” - sírfeliratok filológus szemmel. Fórum. Társadalomtudományi Szemle, 2011/4. 25-26.
} 
A holokauszt után a hatalmas vérveszteség miatt a vidéki zsidó hitközségek százai szüntek meg azonnal, vagy néhány év, esetleg évtized múlva. A központosított hitközségi szervezet évtizedeken át fokozatosan adta el a közösségek nélkül maradt zsinagógákat és más ingatlanokat, melyek többségére a bontás várt. A temetők azonban, a vallási szabályok miatt - nyomós indok nélkül - nem felszámolhatók, nem eladhatók. Egy 1960-as központi helyzetjelentés 822 olyan zsidó temetőröl ír, amelyek fenntartó közössége megszünt, így többségük évtizedekre elhagyatva, elfeledve, gazdátlanul, a sírkőtolvajok és vandálok pusztításának kitéve maradt a települések határában. A jelentés lezárása a korszakra jellemző hozzáállás öszszegzése, az akkori vezetés lényegében lemondott a gazdátlanná vált vidéki zsidó temetőkröl: „, A történelem arra tanít bennünket - ahogy az élet rendjéhez tartozik a halál - a halál rendjéhez tartozik a temetők pusztulása is. "16

Ezek után a kisebb temetők százai évtizedekig gondozatlanul maradtak. A kerítéseket elhordták, a temetők területét sürü bozótos nőtte be, így a kövek pusztulásának mértéke és az ellopott sírkövek hiánya sem tünt fel senkinek. Az egyetlen ismert jelentősebb kísérlet a korszakban a zsidó temetőket is érintő dokumentálásra a Löwinger István és Schmelzer Kornél által - Scheiber Sándor kérésére - 1955 nyarán készített beszámoló a közép- és dél-dunántúli zsidó közösségekröl, amelyben leírták többek között a helyi temető állapotát, és a legrégebbi leolvasható síremlékek évszámait is közölték. ${ }^{17}$

A elhagyott temetőkkel kapcsolatban felmerült az exhumálás és a megóvható temetőkbe való áthelyezés gondolata is, ez azonban országos szinten túlságosan költséges lett volna. ${ }^{18}$ Néhány példát mégis ismerünk a környékbeli falvakból 1956 után a budapesti Kozma utcai vagy a miskolci Avas temetőbe „,beköltöztetett” temetőkre. Több eset is azt bizonyítja, hogy az exhumált maradványok rituális értelemben vett biztonságba helyezése motiválta ezeket az akciókat, és nem feltétlenül járt együtt a terület új célra való használatával. Ilyen például Bia vagy Zsámbék, ahol az egykori zsidó temetők területe ma is megvan, üresen áll. Az áttemetések - ha életben lévő hozzátartozó máshogy nem intézkedett - közös sírba történetek, vagyis az egykori síremlékek elvesztek. Azért is különösen fájó ez, mert a zsámbéki temető egyike volt az újkori Magyarország legkorábbi zsidó temetőinek (1. kép).

A téma több évtizedes elhanyagolása után nagy érdeklődést váltottak ki az 1980-as években megjelenő fotóalbum jellegü, szélesebb közönséghez szóló kiadványok: Erdélyi Lajos Régi zsidó temetők müvészete címü kötete 1980-ban Bukarestben, Wirth Péter Itt van elrejtve címü albuma 1985-ben Budapesten jelent meg. A vizuálisan befogadható értékek felöli közelítés a zsidó sírkövekhez pont ellentétes az egy évszázaddal korábbi nézőponthoz képest. Erdélyi és Wirth fotói

\footnotetext{
16 Toronyi, 2010. 118.

17 Toronyi, 2010. 93-113.

18 Toronyi, 2010. 118.
} 


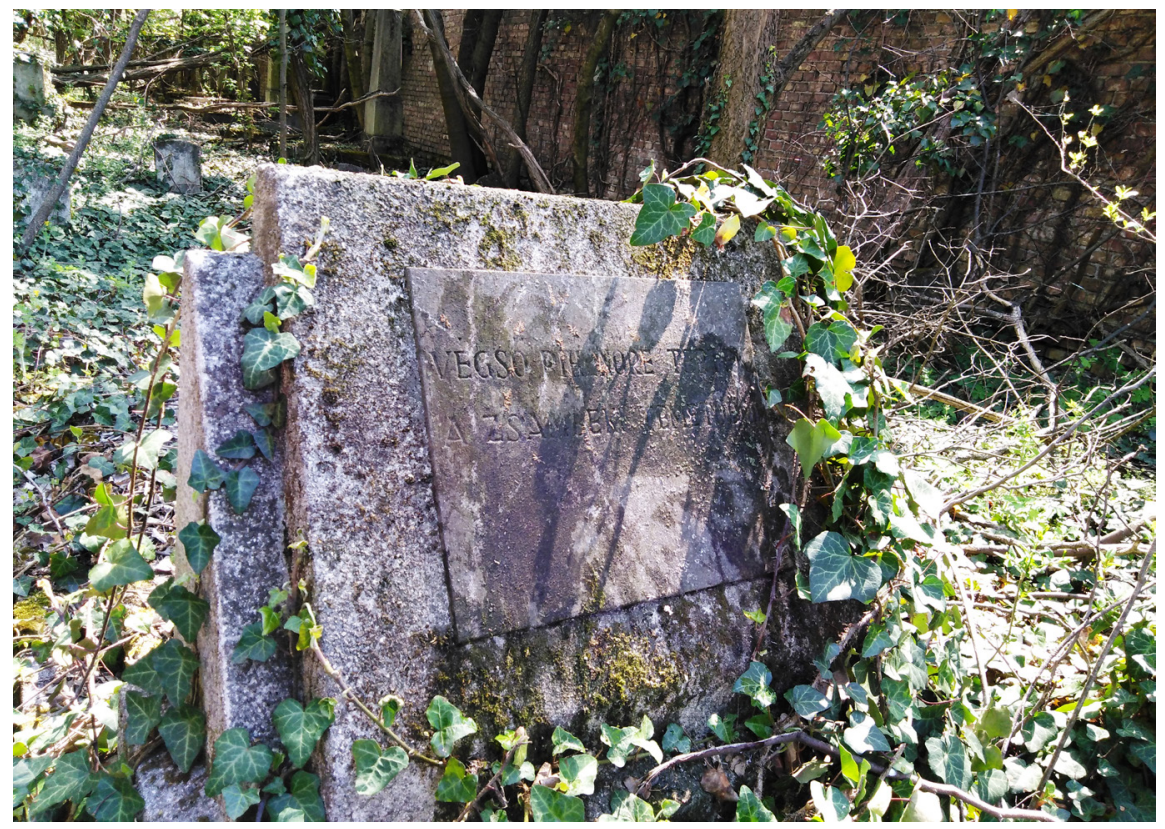

1.kép. A zsámbéki temető exhumált halottainak közös sírjele a Kozma utcai temetőben.

érdeklődést ébresztettek a hazai épített örökség különleges, a pusztulás szélén álló szegmense iránt.

A rendszerváltás időszakában országszerte egyre több helyen kezdődött meg az egykori zsidó közösségek történetének a kutatása, az akkortól megjelenő kötetekben már intenzívebb érdeklődéssel foglalkoznak a temetőkkel is. Ez a szemléletváltás első megközelítésben a képanyagban volt érzékelhető, ami következett abból a körülményből is, hogy vidéken a zsinagógák, hitközségi iskolák, üzletek-lakóházak elbontása, átalakítása után, az emlékezet utolsó hordozói maradtak a temetők. Az elpusztított hitközségi levéltárak, anyakönyvek és családi dokumentumok hiányában, a temetők a megsemmisített zsidó közösségek utolsó emlékeivé váltak, történetük különleges forrásaiként tekinthetünk rájuk.

A zsidó temetők feldolgozását segíti az a körülmény, hogy többségükben, lényegében mintegy 1400 temető esetében lezárt, végleges egységről van szó, így a kutatási keretek egyértelmüek. Mindegyik temető történeti temetőnek tekinthető, többségében hetven éve nem történt temetés; exhumálás is csak néhány kivételes esetben. Ugyanakkor a rongálások, lopások miatt sajnos többségük nem maradt meg eredeti állapotában, sőt, sok közülük részlegesen vagy teljes egészében elpusztult, csak a területe határozható meg, de néhány esetben még az sem pontosan. A pusztulás csak töredékeiben érzékeltethető, mert néhány nagyobb hitközségen kívül sehol sem maradtak fenn a temetőkönyvek, kataszteri térképek. 
Az 1990 után megszületett dokumentációk, feldolgozások változó mélységüek. Vannak példaértékü helyi és regionális kutatások is, ${ }^{19}$ ugyanakkor jellemző, hogy a kutatók többsége a sírköveken látható jelképekkel és motívumokkal csak általánosságban foglalkozik, emellett héber nyelvtudás hiányában rengeteg információ rejtve marad. Az utóbbi 10 évben jelentek meg Kormos Szilvia kutatásai nyomán a váci (2010), a lovasberényi (2012) és a pilisvörösvári (2016) zsidó temetőket feldolgozó kötetek az MTA Kisebbségkutató Intézet Judaisztikai Kutatócsoport kiadásában. Ezek az első magyarországi tudományos publikációk, amelyek közlik egy adott település összes zsidó sírkövének feliratát, továbbá térképeket, elemzéseket, a temetö szélesebb közönség számára való bemutatásával segíti örökségi értékének tudatosítását.

A zsidó temetők felkutatását, általános és részletes dokumentálását célozzák az egyre újabb országos és helyi szintü virtuális adatbázisok. A www.izraelitatemetok.hu mintegy félezer hazai zsidó temető koordinátája mellett rövid szöveges, és néhány fényképet tartalmazó állapotrögzítéssel segíti az adott sírkert iránt érdeklődőket. A www.zstm.hu térképes adatbázisa az összes hazai zsidó temető pontos helymeghatározására törekszik. A makói József Attila Városi Könyvtár és Múzeum honlapján tette közzé a jángori neológ temető összes síremlékének fényképes dokumentációját. ${ }^{20}$ A Magyar Nemzeti Levéltár Békés Megyei Levéltára ezzel szemben egy teljes, kereshető fényképes adatbázist készített, amelyben az egyes elhunytak anyakönyvi adatai is megtalálhatók. ${ }^{21}$

Ugyancsak ebbe az irányba mutatnak az országszerte egyre népszerübb tematikus, örökségvédelmi séták, közösségi programok, amelyeket a helyi múzeumok, helytörténeti egyesületek szerveznek. Budapesten a Nemzeti Örökség Intézete Sírkerti séták címü programsorozatának részeként szervezi A Salgótarjáni utcai zsidó temetö története, valamint a Lajta Béla sirremlékmüvészete a Salgótarjáni utcai zsidó temetőben címü programjait. Szegeden az örökségnapok keretében a 2011 óta szervez a Somogyi Könyvtár Az élők háza elnevezéssel sétát a szegedi izraelita temetőben. ${ }^{22}$ Vasváron 2019-ben a Városnéző séták sorozat állomásaként az újonnan rendezett temetőt járhatták be az érdeklődők, ${ }^{23}$ ugyanebben az évben a Szentesi Vendégszeretet Egyesület Temetői körséták címü programsorozata keretében látogatott el a helyi zsidó temetőbe. ${ }^{24}$ Balatonfüreden a 2018-ban megnyitott Zsidó

19 A teljesség igénye nélkül említhetjük például Ábrahám Vera szegedi és Somogy megyei kutatásait, Balázs Edit nyugat-magyarországi kutatásait és az általa vezetett szakdolgozatok sorát. http://www.muzeum.mako.hu/mako-jangori-zsido-temeto-2/ Azonban az adattár nem kereshető név alapján, és nem tartalmazza a síremlékek mindkét oldalának képét sem. https://mnl.gov.hu/mnl/beml/a_gyulai_zsido_temeto_adatbazisa

$22 \mathrm{https}: / / 24 . \mathrm{hu} /$ belfold/2012/09/21/orokseg-hetvegi-seta-a-181-eves-szegedi-zsido-temetoben/

23 https:/www.vaol.hu/kozelet/helyi-kozelet/varostorteneti-seta-a-zsido-temetoben-markus-sandort-is-meghivtak-vasvarra-3386766/

24 https://www.delmagyar.hu/helyi-ertek/28-embert-temettek-ide-1974-ota-seta-a-szentesi-izraelita-temetoben-4683615/ 
Kiválóságok Háza A füredi rabbi címen rendszeresen tart tematikus városnéző sétát. Az érdeklődők ennek keretében bejárhatják egy klasszikus vidéki zsidó közösség hétköznapjainak útvonalát. Az egykori zsinagóga épülete és a temető mellett felkeresik a rituális fürdő, a rituális metsző háza, valamint a felekezeti iskola hült helyét, eközben a résztvevők megismerkedhetnek a zsidó étkezési, istentiszteleti, családi, házaséleti, tisztálkodási és temetkezési szokásokkal is. ${ }^{25}$

\section{A fizikai állagmegőrzés, a felújítások kérdései}

A holokausztot követően először a legkisebb, néhány családból álló, túlélők nélküli falusi zsidó közösségek temetői váltak gazdátlanná. Az egykori néhányszáz fős hitközségek után maradt szórványközösségek lassabban szüntek meg, tagjaik közül többen a következő másfél-két évtizedben még a településeken éltek. Az elvándorlás újabb hulláma, 1956 után a nagyközségekböl-kisvárosokból is eltüntek a túlélők. Ekkortól sürüsödtek meg a sírkőlopások, amelyeket jellemzően sírkövesek követtek el. Az esetekre többnyire nem derült fény, csak évtizedekkel később, a temetők megtisztítása során. A példaként említhető Békés megyei Csorváson kislétszámú, de jómódú neológ zsidó közösség lakott, a temetőben ma két mükő síremléket találunk, mintegy 12 értékes obeliszknek csak a helye látható. Az elhagyatott zsidó temetők környezetében több helyen találhatók lecsiszolt, majd ellentétes oldalon újravésett gránitoszlopok és gránittömbök. Napjainkig rendszeresen előfordulnak lopások és a rendszerváltás óta több esetben kifejezetten antiszemita jellegű temetőrongálások is. Például 2011-ben a marcali temetőben 75, 2015-ben a gyöngyösi temetőben 15-20 síremléket rongáltak meg (2. kép).

A MIOK, majd a MAZSIHISZ anyagi lehetőségeit mindig messze meghaladta a vidéki temetők fenntartásának feladata. A rendszerváltás után ismét egyre nagyobb számban kezdték felkeresni az elszármazott túlélők és leszármazottaik az ősök síremlékeit a magyarországi temetőkben. Újjáéledtek és egyre jelentősebb számú hívőt vonzottak a köztiszteletben álló rabbik sírjait célzó zarándoklatok, emellett a nemzetközi zsidó temetőrekonstrukciós alapítványok is kiterjesztették müködésüket Magyarországra. Munkájuknak köszönhetően sok ortodox temető sírfeliratainak rögzítésére, a temetők és a nagy rabbik sírjainak felújítására került sor. A Heritage Foundation for Preservation of Jewish Cemeteries (HFPJC) nevü, az Amerikai Egyesült Államokban székelő alapítvány 2002 óta Magyarországon 107 temető kitisztítását és bekerítését támogatta, így például a 18. századi sírkőanyagot is őrző az apostagit, a bodrogkeresztúrit, a gyönkit, a mádit, a paksit, és a tokajit.

25 https:/www.zsidokivalosagok.hu/event/a-furedi-rabbi-zsido-kivalosagok-haza-belepovel-2/2020-08-08/ 


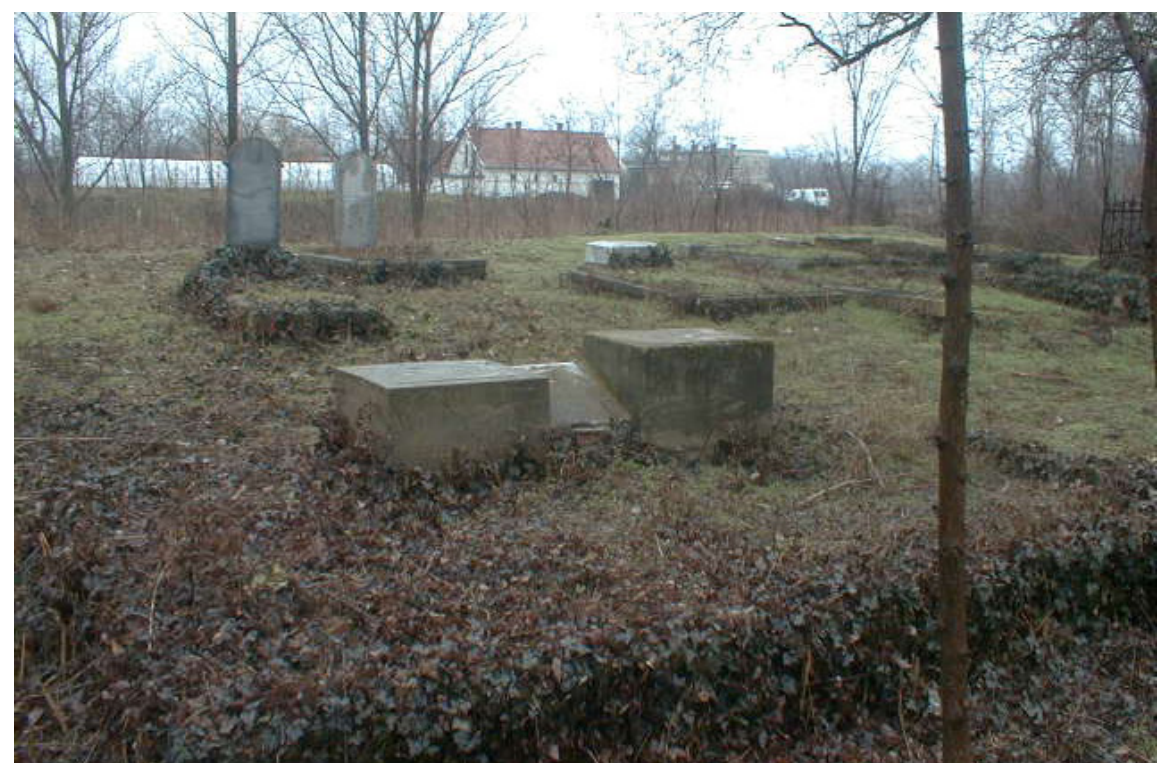

2. kép. A csorvási zsidó temetö képe az ellopott obeliszkek helyével

A fizikai fenntartás, felújítás anyagi hátterében fordulópontot jelentett 2001, amikor a kormány úgy határozott, hogy éves támogatást nyújt a MAZSIHISZ-nek a lezárt zsidó temetők fenntartására. ${ }^{26}$ Ezt követően sok, elfeledett kisebb temető került a MAZSIHISZ Vidéki Temetőrendezési Csoportjának nyilvántartásába és kezdődött meg a rendezésük, gondozásuk. A MAZSIHISZ temetőjegyzékéhez az adatokat az önkormányzatok küldték meg. Jól jellemzi a rendezetlen helyzetet, hogy a telekkönyvi bejegyzésekben még ma is szerepelnek olyan hitközségek tulajdonosként, ahol már 1944-ben sem volt müködő hitközség. 600-700 közötti temető esetében van karbantartási szerződése a MAZSIHISZ-nek a helyi önkormányzattal vagy magánszeméllyel.

2002 és 2014 között zajlott az első nagyszabású, 15 temetőt érintő felújító és értékmentő együttműködés Zala megyében, amelyben zsidó és nem zsidó szervezetek, a Zala Megyei Önkormányzat, a települési önkormányzatok, a Zala Megyei Büntetés-végrehajtási Intézet, a MAZSIHISZ és a Zalaegerszegi Zsidó Hitközség vett részt.

2014-ben kezdte meg a Miniszterelnökség egy pályázaton alapuló támogatási rendszer kialakítását. A pályázatot a Magyarországi Zsidó Örökség Közalapítvány bonyolítja le: először 2018-ban írt ki pályázatot 400 millió forint értékben gondozatlan, elenyészőben lévő zsidó sírkertek, sírhelyek rekonstrukciójára. A pályázaton

$\overline{26}$ Az éves támogatás összege 2015-ben 38 millió forint volt. 
ötven temető különféle munkálatait támogatta a kuratórium, legnagyobb arányban a kerítés építését tartalmazó pályázatokat. A vissza nem térítendő támogatást azzal a feltétellel adták, hogy a helyi önkormányzat vállalja 10 évre a temető gondozását. Jelenleg a rekonstrukciós program második szakasza zajlik, 2020. július 31-én zárult le a pályázatok beadása.

Szintén jelentős állami ráfordítással indultak meg a 2016 óta a Nemzeti Örökség Intézet kezelésben levő budapesti Salgótarjáni úti zsidó temetőben az állagmegőrző, a baleseti veszélyt elhárító munkák, illetve néhány kiemelt sír felújítása. Ez a temető a dualizmus kori, illetve kisebb részben a két világháború közötti fővárosi zsidóság temetkező helye volt, sok müvészettörténetileg is kiemelkedő síremlékkel. A felújítással párhuzamosan megindult történeti-művészettörténeti anyaggyüjtés távolabbi célja a Világörökségi pályázás előkészítése. ${ }^{27}$

Az elmúlt két évtizedben kivitelezett munkálatok vizsgálata alapján kiderül, hogy az egyéni vagy helyben megrendelt, illetve szervezett felújítások, a síremlékek újrafestése, újravésése, új sírkövek felállítása, a tájékoztató táblák elhelyezése, ohelek $^{28}$ felépítése sok esetben a müemlékvédelmi és örökségvédelmi szempontok figyelembe vétele nélkül történt. A temetőképre nézve legmeghatározóbbak az új kerítések kialakítása, valamint az ultraortodox és haszid közösségek temetőlátogató zarándoklatai miatt épülő infrastruktúra. A több évszázad alatt kialakult hagyományos temetőképek egészben, valamint részleteikben is különleges értéket képeznek, azonban rendkívül sérülékenyek. A költséghatékony megoldásként gyakran alkalmazott betonkerítések, ha a gyakorlatban alkalmasak is arra, hogy megvédjék a temetők síremlékeit, tájidegen elemként súlyosan rombolják annak örökségi értékét. Fontos lenne, hogy a különféle felújítások, temetői munkálatok akkor is szakszerü, örökségvédelmi egyeztetéseket követően történjenek meg, ha a temető nem áll védelem alatt (3. kép).

1990 után több zsidó temető került helyi, illetve müemléki védelem alá. 1994ben elsőként a balassagyarmati temető kapott müemléki védelmet, azóta további 12 temető került területi szintü mủemléki védelem alá, valamint két temető esetében a 19. századi temetőrészt nyilvánították műemlékké. Emellett további 31 temető élvez helyi védettséget. A müemlékké nyilvánítás hazai irányelvei szerint a funerális emlék mủemlékké nyilvánításhoz elegendő, ha a védési folyamat során

27 A salgótarjáni úti temető történetének és mủvészettörténeti értékeinek felkutatásában, valamint más közép- és kelet-európai nagyvárosi zsidó temetőkkel való összehasonlításban alapvetőek Csáki Tamás és Klein Rudolf utóbbi években megjelent munkái. L. Csáki Tamás: A Salgótarjáni utcai temető - a pesti zsidó közösség sírkertje, 1874-1891. URBS: Magyar Várostörténeti Évkönyv, 12. 2017. 281-332 és A Salgótarján utcai zsidó temető 1892 utáni történte. URBS: Magyar Várostörténeti Évkönyv, 13. 2019. 261-305; Klein Rudolf: Metropolitan Jewish Cemeteries of the 19th and 20th Centuries in Central and Eastern Europe. A Comparative Study. ICOMOS, Nationalkomitee der Bundesrepublik Deutschland, 2018. Ohel: szó szerint sátor, így nevezzük azt az épületet, amit haszid közösségekben a rabbi és családtagjai sírja fölé emelnek a sír védelmére. 


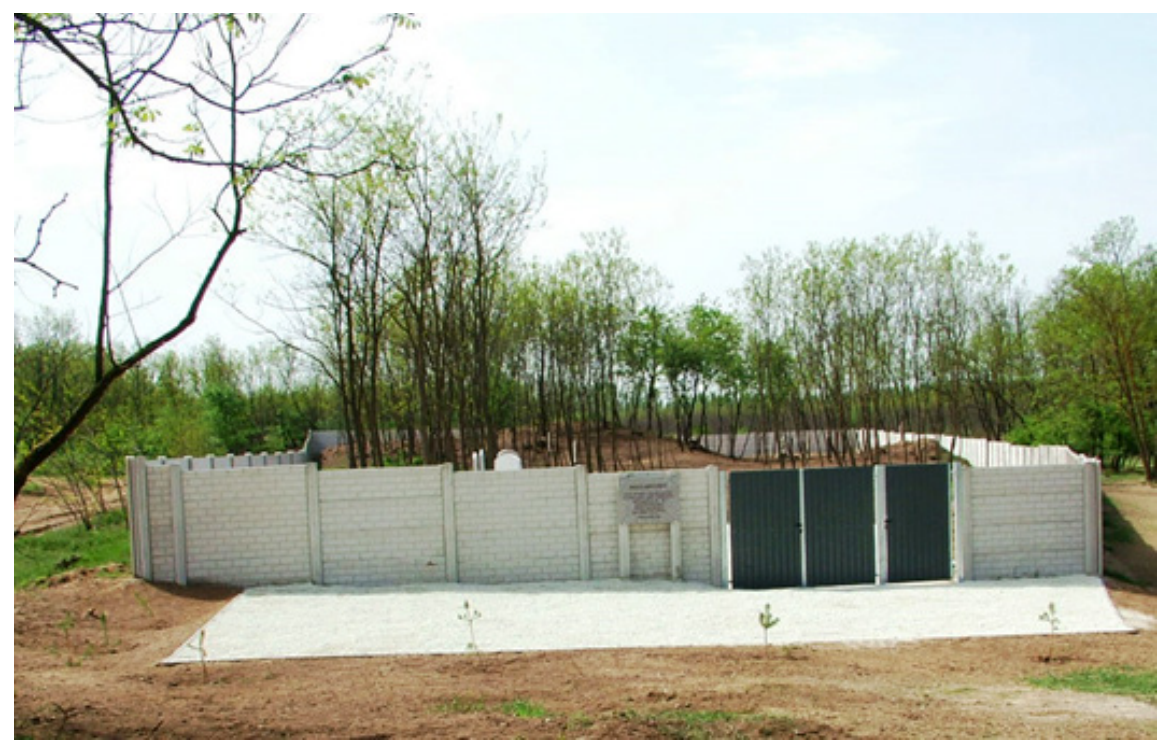

3. kép. Felújitott zsidó temetö betonkeritése (Kisléta)

bebizonyosodik, hogy annak lényeges része korábbi 1830-nál. A müemléki védelem országos szintü kategória, ezzel szemben a helyi védelem önkormányzati hatáskörben történik, célja ,,a településnek és környezetének, valamint az ott található értékes építészeti, táji, valamint az épített környezettel összefüggő természeti elemek jellegzetességének, hagyományos megjelenésének megörzése”. Ennek a hagyományos megjelenésnek a megőrzése kerülhet veszélybe a nem megfelelö felújító munkálatok során (4. kép).

A helyi védelmet élvező temetőkkel együtt jelenleg Magyarországon kb. 150200 temető áll területi védelem alatt, ezek között a zsidó temetők és temetőrészek száma 46, ami a teljes védett temetóállomány harmadát-negyedét jelenti. Ennek a nagy aránynak az egyik oka, hogy a zsidó temetők felszámolását tiltó vallási szabályoknak köszönhetően fennmaradtak a temetők - legalábbis területileg, valamint az egykori közösségek elpusztítása és a túlélők elköltözése miatt nagy részük ma már lezárt, így a további temetések és a védelem szempontjai nem ütköznek.

Ugyanakkor a 46 temető is csak töredéke annak a számnak, ami az irányelv 1830-as időhatárából következne. Balogh Istvánnak a 18. századi alapítású zsidó temetőkre vonatkozó kutatásából tudjuk, hogy a 44 darab, 1800 előtt létesített temetőből csak 14 élvez védettséget. ${ }^{29}$ A nem védett, 1800 elött alapított és

29 Balogh István: A XVIII. századi magyarországi zsidó sírkövek. Analizis és adattár, PhD-értekezés, ORZSE, Budapest, 2019. 
többségükben 18. századi síremlékeket jelentős számban őrző temetők mindegyikének múemlékké nyilvánítása állapotuktól függetlenül sürgető feladat. A nagyon rossz állapotban lévő három temető - Csabrendek, Gyönk és Mágocs - mellett első helyen említendők az országos jelentőségü értéket képező apostagi, bonyhádi, keszthelyi, mádi, makói, miskolci és paksi temetők (5. kép).

Előzetes kutatás alapján további mintegy 160 olyan zsidó temető található Magyarországon, amelyet 1830 elött alapítottak meg, közülük sok helyen a mai napig nagy számban találhatók 1800-1830 között állított síremlékek. Különösen figyelemre méltó ez a szám annak fényében, hogy Lővei Pál a nem zsidó temetői sírjelek számbavétele kapcsán megjegyzi, hogy az 1830/40-nél korábbi emlékek kivétel nélkül dokumentálandók, ugyanis ma már annyira ritkák az ilyen korai emlékek, hogy ez nagyobb időráfordítást sem igényel.

A müemléki védéshez szükséges időhatártól függetlenül minden hazai zsidó temető védendő történeti érték, az adott település sokszínű múltjának része. Hosszú távú megőrzésükhöz és fennmaradásukhoz nélkülözhetetlen, hogy a helyi lakosság a magáénak érezze őket. Szakszerü felújítással és gondozással, bejárási lehetőséggel, jelölötáblákkal és - a kegyeleti jelleg tiszteletben tartása mellett - a 21. században a tanulás és a tudománynépszerüsítés eszközeként elengedhetetlen virtuális

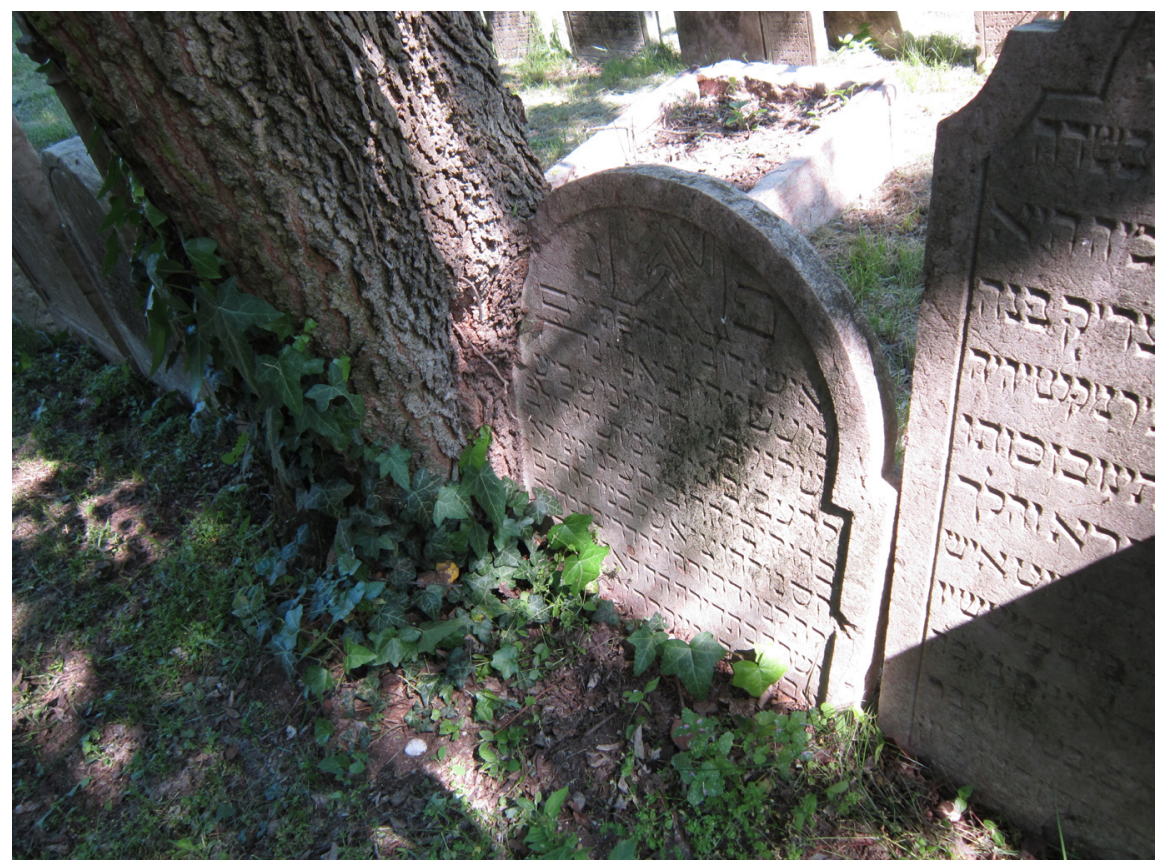

4. kép. 1757-ből származó sírkő a 280 éves tatai müemlék zsidó temetőben 


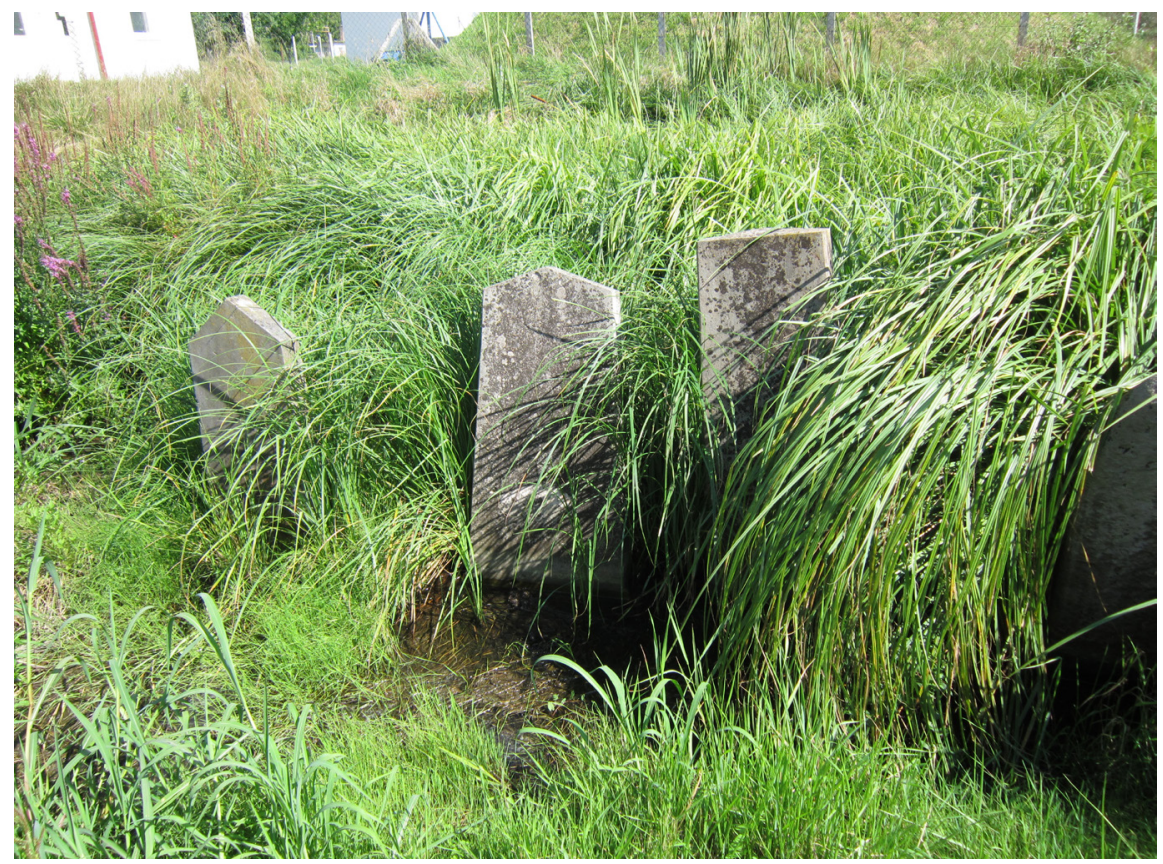

5. kép. A 250 éves gyönki régi zsidó temetö síremlékei máig vízben állnak

felületekkel ellátva, vidéki zsidó temetőink a települések és polgáraik megbecsült értékévé válhatnának, mint az egykori zsidó közösségek kegyeleti parkjai, rendhagyó múzeumai.

\section{FELHASZNÁLT IRODALOM}

Ábrahám Vera: „Hol sirjaink domborulnak” Elhagyott zsidó temetők Somogy megyében. Kaposvár: Olám Alapítvány, 2006.

Balázs Edit (szerk.): Zsidó emlékhelyek a Nyugat-Pannon EuRégióban. Jüdische Erinnerungen in der West-Pannonischen EuRegion. Szombathely: Szombathelyi Magyar-Izraeli Baráti Társaság, 2008.

Balogh István: A XVIII. századi magyarországi zsidó sirkövek. Analizis és adattár, PhD-értekezés, ORZSE. Budapest, 2018.

Bányai Viktória: „Derék asszonyok és jámbor férfiak” - sírfeliratok filológus szemmel. Fórum. Társadalomtudományi Szemle, 2011/4. 25-32.

Csáki Tamás: A Salgótarjáni utcai temető - a pesti zsidó közösség sírkertje, 18741891. URBS: Magyar Várostörténeti Évkönyv, 12. 2017. 281-332 
Csáki Tamás: A Salgótarján utcai zsidó temető 1892 utáni történte. URBS: Magyar Várostörténeti Évkönyv, 13. 2019. 261-305

Csáki Tamás: Lajta Béla funerális épitészete. Budapest: ELTE, PhD-értekezés. 2019

Goldberger Izidor, Macebot ha-risonot be-ir Tata. Hazofeh. VII. (1922), 1. 53-66. Grünvald Fülöp - Scheiber Sándor: Adalékok a magyar zsidóság településtörténetéhez a XVIII. század első felében. In: Magyar-Zsidó Oklevéltár, VII. köt., Budapest: Magyar Izraeliták Országos Képviselete, 1963. 5-48

Klein Rudolf: Metropolitan Jewish Cemeteries of the 19th and 20th Centuries in Central and Eastern Europe. A Comparative Study. ICOMOS, Nationalkomitee der Bundesrepublik Deutschland, 2018.

Kohn Sámuel: Zsidó történelmi emlékek. Különös tekintettel Magyarországra. IMIT Évkönyv, II. (1896). 52-62.

Löw, Leopold: Blumen auf Gräbern. Ben Chananja I. (1858), 433-442

Scheiber Sándor: Magyarországi zsidó feliratok a III. századtól 1686-ig. Budapest: MIOK, 1960.

Toronyi Zsuzsanna: Zsidó közösségek öröksége. Budapest: Magyar Zsidó Levéltár, 2010.

Ujvári Péter (szerk.): Zsidó Lexikon. Budapest: A Zsidó Lexikon kiadása, 1929.

Ulrich, Johann Caspar: Sammlung Jüdischer Geschichten... Basel, 1768.

Wilke, Carsten L.: Medieval Hebrew Inscriptions: Towards a European Database. Jewish Studies at the CEU, VII (2013), 147-172.

Zunz, Leopold: Das Gedächtnis der Gerechten. In: Zur Geschichte und Litteratur. Berlin: Veit und Comp., 1845. 314-458. 